\title{
КОМПОЗИЦИОННЫЕ ТЕНЗОРЕЗИСТИВНЫЕ МАТЕРИАЛЫ НА ОСНОВЕ МАТРИЦЫ ПОЛИБЕНЗИМИДАЗОЛА
}

\section{COMPOSITE PIEZORESISTIVE MATERIALS BASED ON POLYBENZIMIDAZOLE MATRIX}

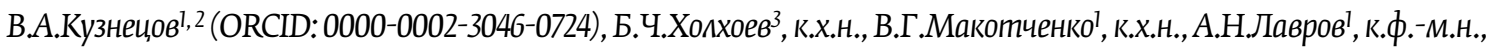 \\ Е.Н.Горенская ${ }^{3}$, А.С.Бердинский², к.т.н., доц., В.Ф.Бурдуковский̌, д.х.н., доц., А.И.Романенко , д.ф.-м.н., проф., \\ B.Е.Федоров ${ }^{1}$,.Х.н., проф./ vitalii.a.kuznetsov@gmail.com \\ V.A.Kuznetsov', 2 (ORCID: 0000-0002-3046-0724), B.Ch.Kholkhoev³, Candidate of Chemical Sciences, V.G.Makotchenko?, \\ Candidate of Chemical Sciences, A.N.Lavrov', Candidate of Physical and Mathematical Sciences, Ye.N.Gorenskaya ${ }^{3}$, \\ A.S.Berdinsky², Candidate of Technical Sciences, Docent, V.F.Burdukovskiï3, Doctor of Chemical Sciences, Docent, \\ A.I.Romanenko', Doctor of Physical and Mathematical Sciences, Professor, V.Ye.Fedorov', Doctor of Chemical Sciences, Professor
}

DOI: 10.22184/1993-8578.2019.12.1.48.58

Получено: 31.01.2019 г.

В статье изучены пленочные композиционные материалы на основе полимерной матрицы полибензимидазола с наноструктурированными углеродными наполнителями. В качестве полимерной матрицы использовался поли-2,2'-п-оксидифенилен-5,5'-дибензимидазолоксид (ОПБИ). Наполнителями служили графитовые нанопластины и малослойный графен. Экспериментально изучен тензорезистивный эффект в пленочных образцах композитов и определены коэффициент тензочувствительности и усталостная прочность. Показано, что в пределах погрешности коэффициент тензочувствительности не зависит от концентрации наполнителя и в среднем равен 15 для МСГ-композитов и 13 для ГНП-композитов. Обнаружено, что тензочувствительность образцов не изменяется до 100 тыс. знакопеременных циклов нагрузки. Измерялись и анализировались температурные зависимости электросопротивления образцов композитов. Установлено, что основной вклад в электросопротивление композитов вносят диэлектрические полимерные прослойки между углеродными наночастицами наполнителя, а электронный транспорт осуществляется туннелированием между этими частицами.

Studied are the film composite materials based on the polymer polybenzimidazole matrix with nanostructured carbon fillers. As a matrix the poly[2,2'-(p-oxydiphenylen)-5, ' $^{\prime}$-bisbenzimidazole] (OPBI) has been used. Graphite nanoplates and few-layered graphene were applied as the fillers. Piezoresistive effect in the film composite samples, strain gauge factor and endurance were studied experimentally. It is shown that the strain gauge factor does not depend on the concentration of filler and, on the average, equal 15 (for FLG composites) and 13 (for GNP composites) within the error. It was found that strain gauge factor of the samples does not change up to 100,000 alternating loading cycles. Temperature dependences of electrical resistance of composite samples have been measured and analyzed. It has been established that the main insulating polymer gaps between the carbon filler nanoparticles make the main contribution to the electrical resistance and conduction mechanism is tunneling between the particles.

Институт неорганической химии им. А.В.Николаева Сибирского отделения Российской академии наук / Nikolaev Institute of Inorganic Chemistry Siberian Branch of Russian Academy of Sciences.

Новосибирский государственный технический университет, кафедра Полупроводниковых приборов и микроэлектроники (ППимэ) / Novosibirsk State Technical University, Department of Semiconductor Devices and Microelectronics.

Байкальский институт природопользования Сибирского отделения Российской академии наук / Baikal Institute of Nature Management, Siberian Branch of the Russian Academy of Sciences. 


\section{ВВЕДЕНИЕ}

Композиционные материалы на основе полимерных матриц с проводящими наполнителями находят все большее распространение в областях, где устоявшиеся полупроводниковые технологии не применимы, в частности в электронике на гибких подложках. В последнее время все больший интерес исследователей привлекают полимерные композиты, как перспективные материалы для электроники. Одним из направлений применения таких новых функциональных материалов является их использование в качестве чувствительных элементов датчиков механических величин. Основываясь на большом количестве опубликованных работ, можно предположить, что такие материалы либо уже находят, либо в ближайшее время найдут применение в производстве тензорезисторов на гибких подложках [1-3]. Принцип работы тензорезисторов основан на тензорезистивном эффекте - эффекте изменения электросопротивления проводника в результате его деформации. На сегодняшний день в качестве полимерных матриц для создания композитов используется широкий ряд полимеров [4], однако слабо изученными остаются композиты на основе матрицы полибензимидазола. Между тем полибензимидазол обладает выдающимися по сравнению с прочими полимерами механическими характеристиками и устойчивостью таких характеристик при высоких температурах $[5,6]$. Для него характерны низкая ползучесть, высокая механическая прочность, фрикционная износостойкость и высокая химическая стойкость. В этой связи композиты на основе полибензимидазола представляются перспективными для использования в качестве тензорезистивных элементов. В качестве проводящей фазы в рамках данной работы предлагается использовать углеродные наночастицы - графитовые нанопластины (ГНП) и малослойный графен (МСГ), как объекты схожие по природе, но с различными аспектными отношениями. В работе приводятся результаты экспериментального исследования параметров тензорезистивного эффекта и температурных зависимостей электросопротивления композитов на основе матрицы полибензимидазола с двумя типами наполнителя - ГНП и МСГ.

\section{СИНТЕЗ И МЕТОДИКА ЭКСПЕРИМЕНТА}

Представитель семейства полибензимидазолов поли-2, 2'-п-оксидифенилен-5, 5' дибензимидазолоксид (ОПБИ) был получен высокотемпературной поликонденсацией 3,3',4,4'-тетрааминодифенилоксида и 4,4'-оксибис(бензойной кислоты) в реагенте Итона по методике, описанной в работе [7]. Для получения композиционных пленок были синтезированы дисперсии (коллоидные системы), представляющие собой частицы графитовых нанопластин или малослойного графена, равномерно распределенные в растворе ОПБИ. В качестве предшественника графитовых нанопластин использовался коммерческий природный графит с размером частиц менее 200 мкм фирмы Merck. Для

\section{INTRODUCTION}

Composite materials based on polymer matrix with the conducting fillers have many uses in the fields where established semiconductor technologies can not be applied, particularly in electronic devices on flexible substrates. Recently the polymer composites attract the ever increasing attention of researchers as the advanced materials for electronics. Application of new functional materials as sensitive elements of the detectors is one of the modern trends in measuring mechanical values. On the base of a large number of publications it can be suggested that such materials are either already used or will soon be used in manufacturing of strain gauges on the flexible substrates [1-3]. The operating principle of strain gauges is based on the piezoresistive effect, when the electrical resistance of a conductor is changed as a result of its deformation.

Nowadays a large number of polymers [4] is used as the polymer matrix for production of composites although the composites based on the polybenzimidazole matrix still have not been studied sufficiently. It should be noted that comparatively to other polymers the polybenzimidazole has the outstanding mechanical properties and stability at high temperatures $[5,6]$.

It has high creep resistance, high mechanical strength and fatigue strength together with the significant chemical resis tance. So, the composites based on polybenzimidazole are pro spective as the strain sensing elements. We proposed to use the carbon nanoparticles - graphite nanoplates (GNP) and few-layered graphene (FLG) as a conductive phase due to their similar ity in nature but with the different aspect ratios. This paper presents the experimental results of 
получения дисперсий навески ГНП смешивались с N-метил-2-пирролидоном (МП) и подвергались двухстадийной ультразвуковой обработке (ультразвуковой технологический диспергатор "Волна" типа УзТА-0.4/22-ОМ, мощность ультразвуковых колебаний 400 Вт, частота 22 кГц). Для получения композиционных пленок использовался супернатант (надосадочная часть дисперсии, то есть без включения осажденных в процессе центрифугирования крупных частиц), составляющий порядка $70 \%$ дисперсии. Толщина частиц ГНП, получаемых таким способом, составляет порядка 10 нм, линейные размеры - от нескольких десятков до сотен нанометров [8]. Методика синтеза малослойного графена описана в работах $[9,10]$. Средняя толщина частиц МСГ составляет 3-4 нм, что при межслоевом расстоянии в образовавшихся графитовых пачках 0,347 нм соответствует 9-12 структурным слоям [10]. Линейные размеры частиц МСГ составляли от нескольких десятков до сотен нанометров. Дисперсии МСГ получали диспергированием необходимого количества МСГ в 2\%-ном растворе ОПБИ в МП. Для получения композиционных пленок с МСГ использовался супернатант, составляющий порядка 90\% дисперсии. Формирование композиционных пленок с ГНП и МСГ осуществлялось по одинаковой методике "полива из раствора": дисперсии выливались на стеклянные подложки и высушивались при температуре $70-80^{\circ} \mathrm{C}$ в течение 24 ч. Таким образом, были получены пленки толщиной порядка 50 мкм, которые затем свободно снимались пинцетом с подложек и дополнительно высушивались в вакууме при температуре $100^{\circ} \mathrm{C}$ в течение 24 ч и на воздухе при $200^{\circ} \mathrm{C}$ в течение 2 ч для удаления остатков растворителя. В данной работе были исследованы пленки с массовыми концентрациями МСГ от 0,25 до 2,00\% и массовыми концентрациями ГНП от 17 до $45 \%$, обозначение композитов далее приводится в виде ОПБИ-МСГ-х и ОПБИ-ГНП-х, где х - массовая концентрация наполнителя, выраженная в процентах.

В рамках работы был определен один из наиболее важных параметров тензорезистивного эффекта - коэффициент тензочувствительности, который представляет собой отношение относительного изменения электросопротивления образца к деформации, вызвавшей это изменение [11]:

$$
\mathrm{K}=\Delta \mathrm{R} /\left(\mathrm{R}_{\varepsilon \min } \cdot \varepsilon\right),
$$

где $\Delta \mathrm{R}=\mathrm{R}_{\varepsilon \max }-\mathrm{R}_{\varepsilon \min }, \mathrm{R}_{\varepsilon \max }$ - электросопротивление образца при деформации $\varepsilon_{\max }, \mathrm{R}_{\varepsilon \min }$ - электросопротивление образца при деформации $\varepsilon_{\min }, \varepsilon=$ $\varepsilon_{\max }-\varepsilon_{\min }, \varepsilon-$ деформация образца (относительное изменение его длины). Для исследования тензорезистивного эффекта экспериментальные образцы приклеивались при помощи лака ВЛ-931 к балкам равного сопротивления изгибу - упругим элементам, трапециевидная форма которых позволяла достичь равномерного распределения деформации по длине образца. Поверхность балок предварительно покрывалась слоем лака ВЛ-931 для piezoresistive effect and temperature dependences of electrical resistance for composites based on the polybenzimidazole matrix with two types of the fillers (GNP and FLG).

\section{SYNTHESIS AND EXPERIMENTAL TECHNIQUE}

A representative of poly benzimidazoles, poly[2,2'-(poxydiphenylen)-5,5'-bisbenzimidazole] (OPBI) was prepared by hightemperature polycondensation of 3,3',4,4'-tetraaminodiphenyl oxide and 4,4'-oxybis (benzoic acid) in Eton's reagent according to the method described in [7]. To prepare the composite films, the dispersions (colloidal systems) consisting of graphite nanoplates particles or few-layered graphene distributed regularly in OPBI solution have been synthesized. The natural commercial graphite with particles lower than $200 \mu \mathrm{m}$ produced by Merck was used as a precursor of graphite nanoplates. Dispersions were obtained by mixing GNP portions with N-methyl2-pyrrolidone (MP) and two-stage ultrasonic treatment (by ultrasonic technological disperser "Volna" UZTA-0.4/22-OM type, power $400 \mathrm{~W}$, frequency $22 \mathrm{kHz}$ ). Supernatant (supernatant of a dispersion, i.e., without particles precipitated while centrifuging) approximately constituting of $70 \%$ of the dispersion was used. In that case the GNP particle prepared by this method is nearby $10 \mathrm{~nm}$ in thickness with linear sizes from tens to hundreds $\mathrm{nm}$ [8]. The synthesis technique to prepare few-layered graphene was described in $[9,10]$. The average thickness of FLC particles is 3-4 nm and corresponds to 9-12 structural layers [10] of graphite particles with interlayer distances of $0.347 \mathrm{~nm}$. Linear dimensions of FLG particles were in the range from tens to hundreds of 


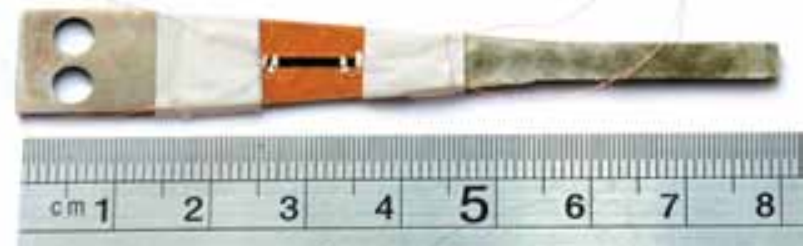

Pис.1. Фотография балки равного сопротивления изгибу с приклеенным образцом композита. На образце видны потенциальные и токовые электрические контакты, выполненные серебряной пастой

Fig.1. Image of the beam of uniform strength (in bending) with the bonded composite sample. It shows potential and current electrical contacts made of silver paste

электрической изоляции образцов. Для обеспечения деформации образцов балка одним концом жестко защемлялась, свободный конец отклонялся с помощью установки, подробно описан ${ }^{-}$ ной в работе [12]. Отклонение свободного конца балки в противоположных от положения равновесия направлениях позволяло в рамках одного эксперимента измерять электросопротивление образцов как при растяжении, так и при сжатии. Экспериментальные образцы представляли собой полоски длиной 7 мм, шириной от 1 до 2 мм. Фотография одного из образцов, закрепленного на балке равного сопротивления изгибу, приведена на рис.1. Электрические контакты к образцам выполнялись серебряной пастой, в качестве подводящих проводников использовалась тонкая медная проволока. Электросопротивление измерялось четырехконтактным методом с использованием источника питания в режиме стабилизации напряжения.

Для исследования электронных транспортных свойств были измерены температурные зависимости электросопротивления образцов. Температура образцов устанавливалась с помощью вставки для погружения в транспортный сосуд Дьюара, в качестве теплоносителя использовался газообразный гелий. Температура измерялась железородиевым термометром сопротивления во всем исследованном диапазоне температур. При низких температурах скорость охлаждения не превышала $0,5 \mathrm{~K} / \mathrm{Mин.} \mathrm{Геометрия} \mathrm{образцов} \mathrm{и} \mathrm{электрические}$ контакты были такие же, как и в случае исследования тензорезистивного эффекта. Для измерения падения напряжения на потенциальных контактах образцов и образцовых катушках сопротивления использовался вольтметр Keithley 2000 со сканирующей платой 2000-SCAN.

\section{РЕЗУЛЬТАТЫ И ИХ ОБСУЖДЕНИЕ}

Тензорезистивный эффект был исследован в образцах композитов ОПБИ-МСГ с массовыми концентрациями МСГ 0,25, 0,75 и 2,00\% и композитов ОПБИ-ГНП с массовыми концентрациями ГНП 17, 30,40 и $45 \%$. nanometers. FLG dispersions were synthesized by sonication of the necessary quantity of FLG in $2 \%$ OPBI solution in MP. It was applied the supernate in quantity of $90 \%$ of the dispersion to obtain the composite films. Composite films with GNP and FLG were prepared with one and the same conditions by the method called "flow coating", when the dispersions were flowed on glass substrates and dried at $70-80^{\circ} \mathrm{C}$ during 24 hours. As a result, the films of about $50 \mu \mathrm{m}$ in thickness were prepared. Afterwards the films were removed from the substrates with a tweezers and have been dried additionally in vacuum at $100^{\circ} \mathrm{C}$ for 24 hours and in air at $200^{\circ} \mathrm{C}$ for 2 hours in order to remove the solvent remained. In this paper the films with mass concentrations FLG and GNP from 0.25 to $2.00 \%$ and from 17 to $45 \%$ were studied. Hereinafter we designate the composites as OPBIFLG- $x$ and OPI-GNP-x, where $x$ is a mass concentration of filler in percentage. One of the most important parameters of the piezoresistive effect - the strain gauge factor, which is the relation of relative change in electrical resistance to the strain that caused this change [11]:

$$
\mathrm{K}=\Delta \mathrm{R} /\left(\mathrm{R}_{\varepsilon \min } \cdot \varepsilon\right),
$$

where $\Delta \mathrm{R}=\mathrm{R}_{\varepsilon \mathrm{max}}-\mathrm{R}_{\varepsilon \mathrm{min}}$, $\mathrm{R}_{\varepsilon \max }$ - electrical resistance of a sample at strain of $\varepsilon_{\max }$, $\mathrm{R}_{\varepsilon \min }$ - electrical resistance of a sample at deformation of $\varepsilon_{\min }$, $\varepsilon=\varepsilon_{\max }-\varepsilon_{\min }, \varepsilon-\operatorname{strain}$ of a sample (relative changes of its length). To study the piezoresistive effect, the experimental samples were bonded with ВЛ-931 glue to the beams of uniform strength (in bending) (which are elastic elements of trapezoidal shape) in order to achieve the uniform distribution of strain along the length of the sample. 


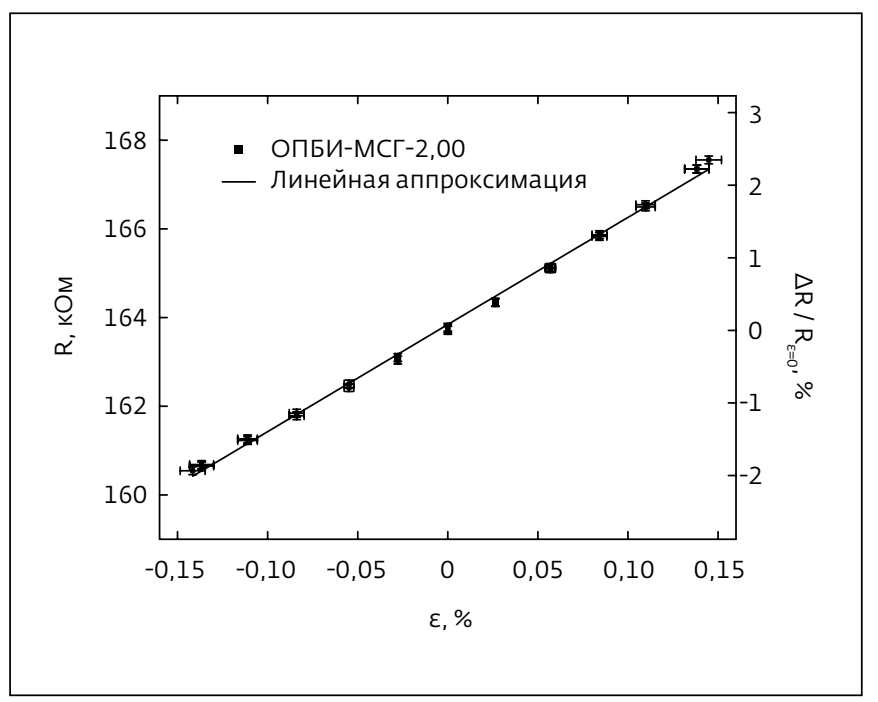

Рис. 2. Зависимость электросопротивления (ось слева) и относительного изменения электросопротивления (ось справа) образца композита ОПБИ-МСГ-2,00 от деформации

Fig.2. Dependence of electrical resistance (left axis) and relative change in electrical resistance (right axis) of OPBI-FLG-2.00 sample on strain

Зависимость электросопротивления и относительного изменения электросопротивления образца композита ОПБИ-МСГ-2,00 от деформации приведена на рис.2. На полученной зависимости видно, что экспериментальные данные могут быть описаны линейной функцией в пределах погрешности в исследованном диапазоне деформаций от $-0,14$ до +0,14\%. Для остальных исследованных

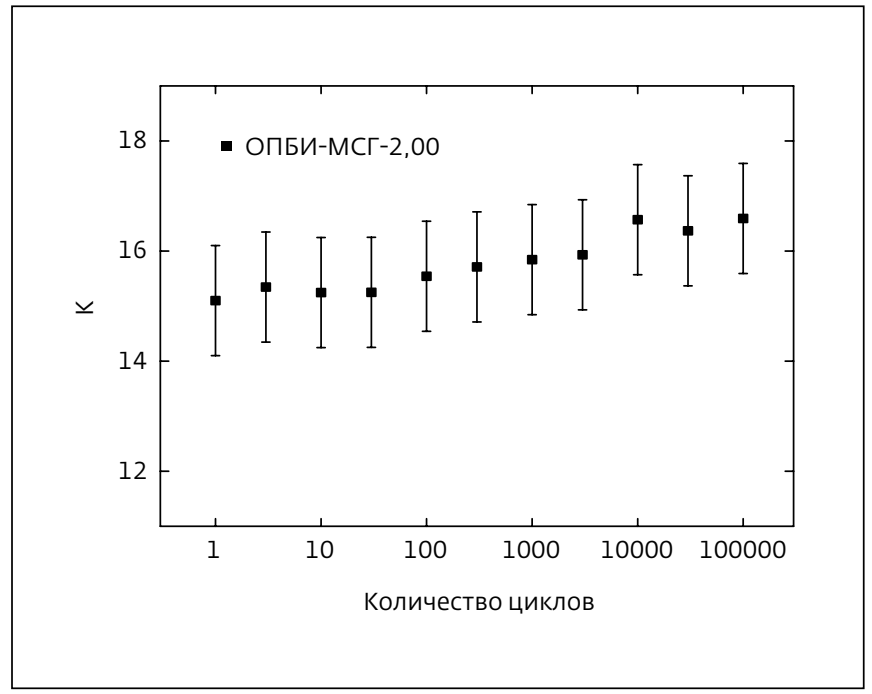

Рис. 3. Зависимость коэффициента тензочувствительности образца композита ОПБИ-МСГ-2,00 от количества циклов сжатия-растяжения при деформации $\pm 0,14 \%$

Fig.3. Dependence of strain gauge factor of OPBI-FLG-2.00 composite sample on the number of compression-tension cycles with strain of $\pm 0.14 \%$

\section{композитов зависимости имеют аналогичный} вид.

Коэффициент тензочувствительности определялся по формуле (1). Для композитов ОПБИМСГ коэффициент составил от 14,4 до 16,6, для композитов ОПБИ-ГНП от 12,1 до 14,5. В пределах экспериментальной погрешности коэффициенты не зависели от концентрации
To insulate the samples, the beams were covered previously with the ВЛ-931 glue layer. Тo ensure deformation of the samples, one end of the beam was rigidly fixed and the free end of the beam was deflected with the device described in detail in [12]. Deflection of the free end of the beam in opposite directions to the balance position makes it possible, in the frame of one experiment, to measure the electrical resistance of the samples both at their tension and compression. Samples were made as strips of $7 \mathrm{~mm}$ long and 1 to $2 \mathrm{~mm}$ wide. Fig. 1 presents the image of the sample bonded on a beam of uniform strength (in bending). Electrical contacts were made with silver paste and leads conductors - of thin copper wires. Electrical resistance was measured using four-contact method with power supply operating in the voltage stabilizing mode.

Temperature dependencies of electrical resistance of the samples were measured to study the electronic transport properties. Temperature was set up by an insert to immerse into the Dewar vessel, helium gas was used as a coolant. Temperature was measured with iron-rhodium resistance thermometer in the range of temperatures studied. The cooling rate at low temperatures did not exceed $0.5 \mathrm{~K} / \mathrm{min}$. Geometry and electrical contacts were the same as in case of when the piezoresistive effect was investigated. Keithley 2,000 voltage meter with the 2,000-SCAN internal scanning plate was used to measure the voltage on the potential contacts of the sample and resistance coils.

\section{RESULTS AND DISCUSSION}

The piezoresistive was investigated in the OPBI-FLG composite samples of mass concentration FLG 0.25, 


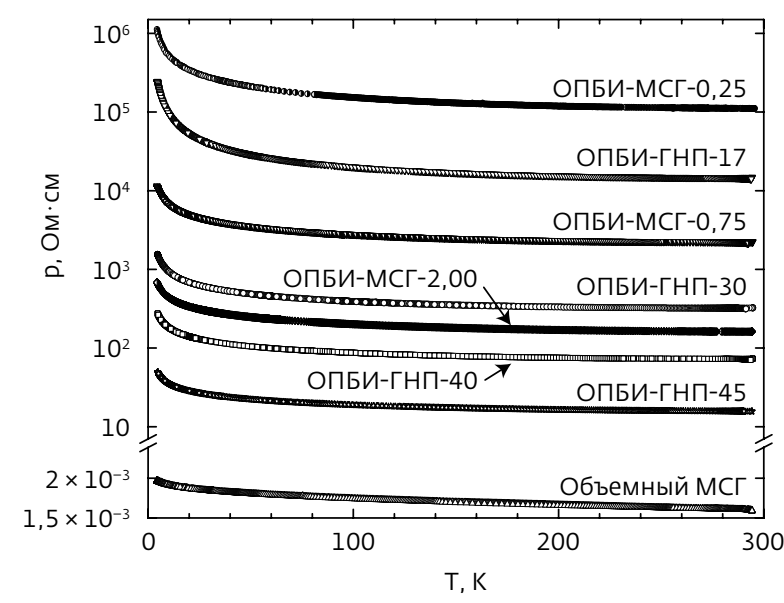

Pис.4. Температурная зависимость удельного сопротивления образцов композитов ОПБИ-МСГ и ОБПИ-ГНП и объемного образиа МСГ

Fig.4. Temperature dependence of OPBI-FLG and OPBI-GNP composite samples and the bulk FLG sample

наполнителей. Зависимость коэффициента тензочувствительности образца композита ОПБИ-МСГ-2,00 от количества знакопеременных циклов нагрузки при деформации џ0,14\% приведена на рис.3, откуда видно, что коэффициент тензочувствительности не изменяется до как минимум 100 тыс. циклов. Такая же стабильность коэффициента тензочувствительности наблюдалась для остальных исследованных образцов композитов.

Температурные зависимости удельного сопротивления образцов всех исследованных композитов приведены на рис.4. В композиционных материалах, представляющих собой диэлектрическую полимерную матрицу с включениями частиц проводящей фазы, электронный транспорт может осу ществляться через контактирующие между собой частицы либо через частицы, разделенные полимерными прослойками. Поскольку дисперсии частиц МСГ и ГНП в растворе ОПБИ являются устойчивыми в течение длительного времени (до месяца и более частицы не выпадают в осадок), то можно заключить, что частицы МСГ и ГНП не коагулируют и окружены раствором полимера. После формирования пленок из таких дисперсий частицы остаются разделенными полимерными диэлектрическими прослойками.

В пользу того, что частицы проводящей фазы окружены диэлектрическими прослойками, говорит и тот факт, что значения удельного сопротивления графита (или образца, состоящего только из частиц МСГ - объемного образца МСГ) и образцов композитов отличаются более чем на четыре порядка. Такую разницу не представляется возможным объяснить в рамках теории перколяции без учета вклада сопротивления диэлектрических прослоек. В противном случае при увеличении концентрации проводящей фазы сначала наблюдалось бы резкое уменьшение удельного сопротивления композита в области порога перколяции и затем слабое уменьшение
0.75 and $2.00 \%$, and OPBI -GNP composites of mass concentration of GNP 17, 30, 40 and 45\%. Fig. 2 indicates the dependence of electrical resistance and the relative change of the electrical resistance of OPBIFLG-2,00 composite on strain of the sample. It was shown that the experimental data may be fitted by linear function within the error accuracy in all studied range of strain (from $-0.14 \%$ to $+0.14 \%$ ). All studied composites present the same shape of the curves.

The strain gauge factor was determined by the formula (1). Coefficient values for OPBI-FLG and OPBI-GNP composites were from 14.4 to 16.6 and from 12.1 to 14.5 , correspondingly. The obtained factor did not depend on the concentrations within the error. Fig. 3 presents the dependence of the strain gauge factor for OPBIFLG-2,00 composite sample on the number of alternating loading cycles with $\pm 0.14 \%$ strain. It is shown that the strain gauge factor is stable up to 100,000 cycles. The same stability was observed for all studied samples.

Fig.4 shows the temperature dependences of resistivity for all studied composite samples. In the composite materials that present a insulating matrix with the conductive phase particles the electron transport can be effected by the particles contacting each other or particles separated with polymer gaps. Due to stability of the dispersions of the FLG and GNP particles in the OPBI solution for a long time (up to a month and longer without sedimentation), can be concluded that FLG and GNP particles are not coagulated and are surrounded by the polymer solution. After the films of such dispersion have been formed, the particles remain separated by the insulating polymer gaps.

The fact that the particles of the conducting phase are surrounded by insulating gaps is supported by the fact that the value of resistivity of graphite 


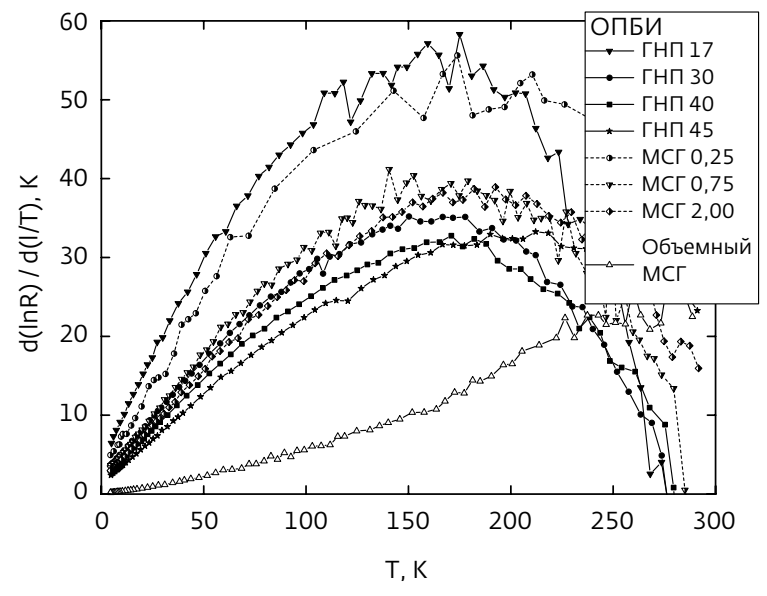

Pис.5. Температурные зависимости величины производной $d(\operatorname{InR}) / d(1 / T)$ для экспериментальных данных, приведенных на рис. 4

Fig.5. Temperature dependences of the values of derivative $d(\ln R) / d(1 / T)$ for the experimental data in Fig.4

сопротивления при дальнейшем увеличении концентрации. Однако такая картина не наблюдается.

Наполнители МСГ и ГНП в исследованных композитах представляют собой наночастицы полуметаллического графита. Протекание тока в образце осуществляется по путям, включающим такие наночастицы, разделенные диэлектрическими полимерными прослойками. Возможны два механизма преодоления потенциальных барьеров, образованных диэлектрическими прослойками - надбарьерное прохождение носителей заряда и туннелирование. Из температурных зависимостей электросопротивления образцов можно оценить величину эффективной энергии активации проводимости, которая в случае только надбарьерного прохождения носителей заряда представляла бы собой высоту потенциальных барьеров, образованных прослойками. На рис.5 приведены зависимости $\Delta_{\mathrm{eff}}$ $\approx \mathrm{d}(\ln \mathrm{R}) / \mathrm{d}(1 / \mathrm{T})$ (эффективная энергия активации проводимости, выраженная в единицах температуры, К) от температуры. Из полученных зависимостей видно, что при любом значении температуры соответствующие значения $\Delta_{\text {eff }}$ меньше данной температуры. Это значит, что если бы имело место только надбарьерное прохождение носителей, то при любой температуре термическая активация позволяла бы носителям заряда свободно преодолевать такие барьеры $\left(\mathrm{T}>\Delta_{\mathrm{eff}}\right)$ (см. рис.5). В таком случае электросопротивление образцов определялось бы электросопротивлением частиц проводящей фазы и топологией перколяционной сетки. Такая модель транспорта не позволяет объяснить увеличение удельного сопротивления композитов на много порядков величины. Соответственно можно заключить, что электронный транспорт осуществляется главным образом туннелированием между полуметаллическими частицами проводящей фазы через диэлектрические прослойки полимера.

Туннелирование является температурнонезависимым механизмом проводимости, но при (or a sample consisting only of particles of GNP - bulk sample of FLG), differ from the value of resistivity of the composite samples by more than four orders of magnitude. This difference cannot be explained by the percolation theory without taking into account the influence of the insulating gaps. Otherwise, with an increase in concentration of the conducting phase, a sharp decrease in resistivity of the composite near the percolation threshold would have been firstly observed, and then a slight decrease in resistivity with a further increase in the concentration. However, this type of behavior is not observed.

Fillers of FLG and GNP composites are the nano-scale particles of semimetallic graphite. Electrical current in a sample flows through the nanoparticles separated by the insulating polymer gaps. There are two possible mechanisms of overcoming the potential barriers involved by the gaps: abovebarrier transitions of the charge carriers and tunneling. It is possible to estimate the effective activation energy from temperature dependences of electrical resistance of the samples. In case of the only above-barrier transitions it would have been equal to the height of the potential barrier involved by the insulating gaps.

Fig.5 presents temperature dependences of $\Delta_{\text {eff }} \approx \mathrm{d}(\ln \mathrm{R}) / \mathrm{d}(1 / \mathrm{T})$ (effective conductivity activation energy expressed in units of temperature, K). As one can see, at any temperatures the values of $\Delta_{\text {eff }}$ are lower than the corresponding temperature. This fact means that were the above-barrier transitions of charge carriers the only electron transport mechanism, the termal activation would have allowed the charge carriers overcoming the barriers at any temperatures $\left(\mathrm{T}>\Delta_{\text {eff }}\right)$ 
этом на зависимостях, приведенных на рис.4, наблюдается увеличение электросопротивления образцов при понижении температуры. Данный факт может быть объяснен следующим образом. Поскольку наполнители МСГ и ГНП представляют собой наночастицы полуметаллического графита с относительно малой плотностью состояний, то за счет размера частиц и наличия в них дефектов спектр разрешенных состояний в частицах будет дискретным. С учетом дискретного спектра транспорт будет осуществляться туннельными переходами ("прыжками") между различными по энергии локализованными состояниями. Чем ниже температура, тем меньшее количество незанятых с доступной энергией состояний имеется в системе, и, как результат, тем на большие расстояния осуществляются такие туннельные переходы. То есть понижение температуры ведет к увеличению электросопротивления композита. Данный механизм электронного транспорта имеет характер прыжковой проводимости с переменной длиной прыжка. При повышении температуры расстояние прыжков уменьшается вплоть до толщины диэлектрических прослоек.

Изменение в широком диапазоне концентрации проводящей фазы не приводит к изменению механизма электронного транспорта. Отсюда следует, что физическая природа наблюдаемого тензорезистивного эффекта заключается в изменении электросопротивления туннельных контактов при деформации образцов.

\section{выводы}

В рамках настоящей работы были исследованы композиционные материалы на основе матрицы полибензимидазола с углеродными наноструктурированными наполнителями, малослойным графеном и графитовыми нанопластинами, в качестве тензорезистивных элементов. Показано, что коэффициент тензочувствительности образцов композитов ОПБИ-МСГ и ОПБИ-ГНП не зависит от размеров частиц проводящей фазы и их концентрации в исследованном диапазоне. Исследование электронного транспорта показало, что основной вклад в электросопротивление композитов вносят диэлектрические прослойки, а электронный транспорт осуществляется туннелированием между частицами МСГ или ГНП через такие прослойки. Изменение в широком диапазоне концентрации проводящей фазы не приводит к изменению механизма электронного транспорта. Исследованные образцы композитов проявляют устойчивость к длительным циклическим нагрузкам, коэффициент тензочувствительности не изменяется до 100 тыс. циклов сжатия-растяжения. Полученные данные позволяют заключить, что тензорезистивные элементы на основе матрицы полибензимидазола являются перспективными для создания сенсоров механических величин, тензорезисторов.

\section{БЛАГОДАРНОСТИ}

Работа выполнена в рамках государственных заданий ИНХ СО РАН в области фундаментальных (see Fig.5). In this case electrical resistance of the samples would have been determined by electrical resistance of conductive phase particles and percolation network topology. This model can not explain the increase of composite resistivity by many orders of magnitude.

Hence, it was proposed to explain the behavior of electronic transport by the tunneling of charge carriers through the insulating polymer gaps between the semimetallic conducting phase particles.

It is well known that tunneling is a temperature-independent mechanism of electrical conductivity, however, Fig.4 shows increasing electrical resistance of the samples while the temperature decreases. We explain this fact as follows. Because the FLG and GNP fillers are the nanoparticles of semimetallic graphite with defects and with relatively small density of states, the allowed states spectrum in the particles will be discrete. Accordingly, the electron transport will be carried out by the tunneling transitions (hoppings) between the localized states of different energy. The lower the temperature, the smaller quantity of unoccupied states with available energy in the system, and, as a result, the tunneling transitions become longer. That is decreasing of the temperature leads to an increase of the electrical resistance of the composite. This mechanism of electron transport has a character of the variable range hopping conduction mechanism. As the temperature rises, the hopping length decreases down to the thickness of insulating gaps.

Changes of the conductive phase concentration do not lead to the changes in the electron transportmechanism. It means that the physical nature of the 
научных исследований (исследование электрофизических свойств композиционных материалов, получение малослойного графена) и Байкальского института природопользования СО РАН (получение функциональных полимерных композитов), при поддержке РФФИ в рамках научного проекта № 18-33-00655 мол_а (получение устойчивых дисперсий графитовых нанопластин).

\section{ЛИТЕРАТУРА}

1. Yu X.W., Cheng H.H., Zhang M., Zhao Y., Qu L.T., Shi G.Q. Graphene-based smart materials // Nature Reviews Materials. 2017. Vol. 2. № 9. P. 13.

2. Hu N., Karube Y., Arai M., Watanabe T., Yan C., Li Y., Liu Y., Fukunaga H. Investigation on sensitivity of a polymer/carbon nanotube composite strain sensor // Carbon. 2010. Vol. 48. № 3. P. 680687.

3. Pham G.T., Park Y., Liang Z., Zhang C., Wang B. Processing and modeling of conductive thermoplastic/carbon nanotube films for strain sensing // Composites Part B-Engineering. 2008. Vol. 39. № 1. P. 209-216.

4. Kuilla T., Bhadra S., Yao D., Kim N.H., Bose S., Lee J.H. Recent advances in graphene based polymer composites // Progress in Polymer Science. 2010. Vol. 35. № 11. P. 1350-1375.

5. Chung T. A Critical review of polybenzimidazoles // Journal of Macromolecular Science, Part C. 1997. Vol. 37. № 2. P. 277-301.

6. Vogel H., Marvel C.S. Polybenzimidazoles, new thermally stable polymers // Journal of Polymer Sci- ence Part A-Polymer Chemistry. 1996. Vol. 34. № 7. P. 1125-1153.

7. Ueda M., Sato M., Mochizuki A. Poly(benzimidazole) synthesis by direct reaction of diacids and tetramine // Macromolecules. 1985. Vol. 18. № 12. P. 2723-2726.

8. Kholkhoev B.C., Gorenskaya E.N., Bal'zhinov S.A., Farion I.A., Batorova G.N., Nomoev A.V., Timashev P.S., Radnaev B.R., Chailakhyan R.K., Fedorov V.E., Burdukovskii V.F. Functional compos ites based on polybenzimidazole and graphite nanoplates // Russian Journal of Applied Chemistry. 2016. Vol. 89. № 5. P. 780-786.

9. Makotchenko V.G., Grayfer E.D., Nazarov A.S., Kim S., Fedorov V.E. The synthesis and properties of highly exfoliated graphites from fluorinated graphite intercalation compounds // Carbon. 2011. Vol. 49. № 10. P. 3233-3241.

10. Makotchenko V.G., Makotchenko E.V., Pinakov D.V. The ways of use of multilayered graphene in engineering ecology // Environmental Science and Pollution Research. 2016. Vol. 24. № 3. P. 2402-2411.

11. Experimental structure analysis / Metallic bonded resistance strain gages - Characteristics and testing conditions. Dusseldorf: Verein Deutscher Ingenieure. 2007. P. 1-40.

12. Kuznetsov V.A., Berdinsky A.S., Ledneva A.Y., Artemkina S.B., Tarasenko M.S., Fedorov V.E. Strain-sensing element based on layered sulfide $\mathrm{Mo}_{0.95} \mathrm{Re}_{0.05} \mathrm{~S}_{2} / /$ 38th International Convention on Information and Communication Technology, Electronics and Microelectronics (MIPRO) / Biljanovic P. New York: IEEE. 2015. P. 15-18. piezoresistive effect is in changes of electrical resistance of tunneling contacts at deformation of the samples.

\section{CONCLUSIONS}

This paper presents the research of composite materials based on polybenzimidazole matrix with nanostructured fillers, few-layered graphen and graphite nanoplates as the strain sensing elements. It was shown that the strain gauge factor of OPBI-FLG and OPBI-GNP composites did not depend on conductive phase particle sizes and their concentration in all studied range. It was observed that the insulating gaps made main contribution to the composite electrical resistance, and the electron transport is carried out by tunneling between FLG or GNP particles through the gaps. Changes in the conductive phase concentration in the wide range do not lead to change of the mechanism of electronic transport. The studied composite samples are resistant to long-term cyclic loadings and their strain gauge factor does not change up to 100,000 compression-tension cycles. The obtained experimental data confirm that the strain sensing elements based on polybenzimidazole matrix are promising for creation of the mechanical quantities sensors, strain gauges in particular.

\section{ACHNOWLEDGEMENTS}

The research was supported by the Ministry of Science and Education of the Russian Federation, NIIC SB RAS (study of electrical properties of composite materials, synthesis of fewlayered graphene) and the Baikal Institute of Nature Management, Siberian Branch of the Russian Academy of Sciences (production of functional polymer composites), with the support of the RFBR grant No. 18-33-00655 mol_a (production of stable dispersions of graphite nanoplates). 